\title{
(2)
}

МРНТИ 68.47.75

УДК 351

https://doi.org/10.51579/1563-2415.2021-1.19

\section{STRUCTURAL MECHANISMS FOR IMPLEMENTING PROJECT MANAGEMENT IN GOVERNMENT BODIES}

"G. Sultanova, Zh. Subebayeva, S. Aitkulova, A. Kendjassarova

"Zhetysu University n.a. I. Zhansugurov» NP JSC, Taldykorgan, Kazakhstan

e-mail:king_bara@mail.ru

Annotation. The article considers that the theory and methodology of project management and project management are currently the basis of public administration in all developed countries. Within this area, national and international standards have been approved, and the relevant legislative framework has been formed. In Kazakhstan, the project management paradigm is also adopted at the state level. An example of this is the adoption of priority national projects - "Affordable and comfortable housing", "Health", "Quality education", "development of the agroindustrial complex", which" permeate " all levels of government. In other words, the field of management, called "project Management" and "Project management", in the context of the transition to an innovative development model, becomes the subject of close attention of Kazakhstan scientists, specialists and managers of both commercial organizations and Executive authorities at all levels of government. The reason for this is the global recognition of project management as a modern philosophy of effective and efficient management.

Key words: public administration, project management, administrative reform, management, state.

Currently, the theory and methodology of project management and project management are the basis of state and municipal management in all developed countries. Within the framework of this direction, national and international standards have been approved, and the relevant legislative framework has been formed. In the Republic of Kazakhstan, the project management paradigm is also adopted at the state level. An example of this is the adoption of priority national projects — "Affordable and comfortable housing", "Health", "Quality education", "Development of the agro-industrial complex", which" permeate " all levels of state and local government.

Main provisions of the article.

Restriction of state intervention in the economic activities of business entities, including the termination of excessive state regulation.

Elimination of duplication of functions and powers of executive authorities.

Development of a system of self-regulating organizations in the field of economics.

Organizational division of functions of regulation of economic activity, supervision and control, management of state property and provision of services by state organizations to citizens and legal entities.

Completion of the process of delineation of powers between the executive authorities and the authorities in the regions, optimization of the activities of the territorial executive authorities.

Introduction. Project management covers those areas of public, state and industrial activity in which the creation of a product or service is implemented as a unique set of interrelated targeted activities with certain requirements for the timing, budget and quality of the expected result. Rapidly developing over several decades, project management today is a synthetic discipline that combines methods, tools, and best practices from several different fields of Economics and management. At the same time, it has its own methodologies, tools, and standards. It should be noted that in the Russian literature, the term " project management "is often mistakenly identified with the term" project management". The main difference between these concepts is in the object of management: the object of project management is organizations that have switched to the ideology of project management in General, and the object of project management is specific projects (programs) [1].

A peculiar indicator of the recognition of the effectiveness of the use of project management methods was adopted as the first main direction for fulfilling the requirements of the reform within the framework Of the concept of administrative reform in Kazakhstan until 2025 "implementation of methods and procedures for results-based management and project management in the Government of the Republic, Executive authorities, Executive authorities of regions and regions and organizations subordinate to state bodies". In addition, the reform of public administration itself is a complex project, decomposed into a number of smaller projects, which is noted in the text of the concept itself [2].

In fact, the administrative reform involves a set of measures in the following priority areas:

- limiting state interference in the economic activities of business entities, including the termination of excessive state regulation;

- elimination of duplication of functions and powers of Executive authorities;

- development of a system of self-regulating organizations in the field of Economics; 
- organizational division of functions of regulation of economic activity, supervision and control, management of state property and provision of services by state organizations to citizens and legal entities;

- completion of the process of division of powers between Executive authorities, optimization of the activities of territorial Executive authorities [3].

To implement each of these areas, it is planned to implement a set of projects aimed at creating conditions for the transition to a new basis of public administration. Thus, project management permeates the entire Concept of administrative reform.

A thorough analysis of the document "the Concept of administrative reform in the Republic of Kazakhstan until 2025" allows us to note that specific methods of transition to the ideology of project management are not proposed in this document, but it is indicated that "in order to implement the procedures for results-based management and project management, an appropriate standard regulatory and methodological base should be created with its subsequent experimental testing".

Methodology. Modern methods were used in the research: abstraction, systematic, logical and comparative analysis, generalization, synthesis, methods of proof, analogies, modeling, economic and historical analysis, monographic method, system approach.

Information support for the study was provided by legislative and regulatory acts of the Republic of Kazakhstan, data from periodicals related to the reform and integration of state bodies and project development systems.

The theoretical and methodological basis of the research is the main provisions contained in the scientific works of domestic and foreign economists on the problems and prospects of creating an integrated system of state bodies; legislative and regulatory acts on the subject of research; Kazakhstan and international regulations (standards) on project development; scientific and methodological literature; periodicals; materials of scientific conferences and seminars.

Results. The increasing pressure of external factors caused by the unstable development of the world economy, the decline in demand and prices for raw materials, the continuation of sanctions between Western countries and Russia, has negative consequences for the socio-economic development of Kazakhstan. In such crisis conditions, the relevance of rational and effective use of funds allocated by the state for the implementation of state projects and programs increases. It is proposed to introduce a project management system of the Government of the Republic of Kazakhstan, as it will determine the order of project activities of the Government: the system of bodies and the role structure of project activities. This will be a new format of work for the authorities and a kind of instruction on the effective implementation of projects. It will also provide a routine description of the process: how to initiate projects, who and how is responsible for their implementation, who and how controls the results. It was noted that to date, work is actively underway to implement the project management system in the public sector of the Republic of Kazakhstan [4]. The article considers the phased implementation of the project management system in the state bodies of the Republic of Kazakhstan. The authors reviewed the current legislative framework, identified gaps in the field of public administration. Based on the analysis, using the information modeling approach, the current model of project management elements is built, which cover all elements of the project management methodology of the best world practices. The authors propose an algorithm for implementing the project management system in the state bodies of the Republic of Kazakhstan. Before implementing a project management system in a government Agency, it is necessary to analyze the maturity of the organization, i.e. identify at what stage of maturity the organization is, since the implementation of project management implies, at a minimum, a process approach.

In modern management theory, as is known, there are five levels of maturity of an organization in process management [5], each of which has certain characteristics:

Level 1-the process being performed (the necessary resources, main parameters and results are defined);

Level 2-managed process (defined targets, reporting, process control and adjustment procedures);

Level 3 - established process (standards are set for the process, the process is performed based on standards);

Level 4-predictable process (process parameters are related to the organization's goals);

Level 5 - process being improved (process improvement goals that correspond to the organization's goals are defined, sources of existing and potential problems are identified, opportunities for process improvement are provided, and change management is provided) [6].

To implement project management in the state system of Kazakhstan, we conducted an analysis of the maturity of state bodies based on process management. According to the results of the analysis, it was revealed that the level of maturity of state bodies is currently at the lowest stage.

As we can see, the second stage provides an algorithm for implementing process management. We have not only designed the processes, but also defined specific requirements for the human resources needed to complete them.

We started by structuring all the processes. Then we developed process specifications that became the basis for the formation of employees 'job responsibilities and determining the composition of specialists' competencies. Thus, acting strictly consistently, we have built profiles of professional positions.

It is important to emphasize that the requirements for performers are formulated on the basis of our analysis of business processes. Implementation of the process approach means that the organization uses a quality management system (QMS).

After the implementation of the process approach, it is necessary to conduct a compliance assessment, i.e. to assess the level of readiness of the state body to implement project management. 
At the third stage, we have described the algorithm for implementing project management, i.e., based on the current legislative framework, we have shown where to fill in the existing gaps in order to build an integrated system for managing project activities in state bodies, including organizational, methodological and information support.

The implementation of project management in government agencies across the country is a large-scale project in itself. Therefore, its implementation should also be divided into successive stages:

- organizational (system formation, distribution of functions);

- methodological (development of regulations, regulations and other documentation);

- technological (creation of a common information system for all EB (Executive bodies));

- training (assessment and approval of competencies, training of specialists). All projects in government bodies (state) are divided into three types:

- priority - key initiatives that are personally controlled by the head of the body;

- internal - implemented by EB divisions;

- external - implemented by external organizations under the control of the authority [7].

National standards RK 54869-71-2011, as well as proven specialized planning tools are used - computer programs MS Project, Spider Project, Primavera and others. In order to organize work at different levels, project offices (basic, managerial, or strategic) are created in the regions. They include interacting curators from the customer and contractor teams and, accordingly, industry and project managers.

Conclusions. To overcome the inertia of the managers of the old school and modernize the structure of the public sector and local government, it is necessary to pay special attention to such areas of activity:

- continuous training of staff, as the governing and ordinary level to improve specific competences to solve specific professional tasks; to certify personnel according to modern management standards;

- to promote employee motivation (material and moral), on the basis of personal effectiveness and overall success of the undertaking, organize the feedback by managers;

- when implementing the principles of PM in an organization, move from simple initiatives to complex multi-component initiatives;

- record the results of each stage, identify its shortcomings and benefits, make necessary changes to the passport and record them again;

- maintain the integrity of the initiative in all areas of work (from initiation to acceptance and final report);

- clearly distribute roles and responsibilities among employees in order to avoid poor performance of assigned functions.

In conclusion, it should be noted that this model also has a number of disadvantages characteristic of the matrix management structure, which is noted by project management specialists, but in General it allows you to implement project management with minimal changes and losses, which is a serious factor for the above-mentioned bodies and organizations.

Thus, following the proposed algorithm, in our opinion, in Kazakhstan it is possible to implement project management in state bodies, which will increase the efficiency and effectiveness of their activities.

\section{List of references:}

1 Т. С. Нарбаев. Оценка зрелости управления проектами в Казахстане // Управление проектами и программами. - (2016). - № 2(46). - С. 144-163. [Электронный ресурс]. — Режим доступа: https://www.researchgate.net/publication/309904368 Ocenka zrelosti_Upravlenia proektami_v_Kazahstane.

2 Ойнаров А. Р. Методологические основы управления проектами: монография / А. Р. Ойнаров. Астана: Казахстанский центр государственно-частного партнерства. - 2015. - С. 42-46.

3 Бияк Л. Л. Роль проектного менеджмента в реализации приоритетных государственных проектов // Актуальные вопросы экономики и управления: материалы V Международного журнала. научной конф. БукиВеди. -2017. - С. 12-15. - URL: https://moluch.ru/conf/econ/archive/222/12543/ (дата обращения: 04.10.2020).

4 Приказ Министра национальной экономики Республики Казахстан от 5 ноября 2014 года № 69 "Об утверждении Положения о Министерстве национальной экономики Республики Казахстан". [Электронный pecypc]. — Режим доступа: http://adilet.zan.kz/rus/docs/V

5 Тхориков, Б. А. Основные элементы проектного управления в государственном секторе// Актуальные вопросы экономики и управления: материалы V Международного журнала. научной конф. (Москва, июнь). Буки-Веди. - 2017. - С. 138-142.

URL: https://moluch.ru/conf/econ/archive/222/12235/ (дата обращения: 04.10.2020).

6 Национальный стандарт Республики Казахстан СТ РК ИСО 21500-2014 "Руководство по управлению

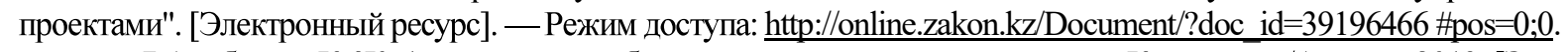

7 Алибекова К. Ж. Актуальные проблемы современного менеджмента в Казахстане /Астана. -2013. [Электронный ресурс]. — Режим доступа: http://www.rusnauka.com/16 NPRT 2012/Economics/1 111536. doc.htm. 
List of references(транслитерация):

1 Narbaev T. S. Otsenka zrelosti upravleniya proektami v Kazakhstane (Project management maturity assessment in Kazakhstan), Upravlenie proektami i programmami, 2016, No. 2(46), pp. 144-163. [Elektronnyi resurs]. — Rezhim dostupa: https://www.researchgate.net/publication/309904368_Ocenka_zrelosti_Upravlenia_proektami_v_ Kazahstane.

2 Oinarov A. R. Metodologicheskie osnovy upravleniya proektami (Methodological foundations of project management), monografiya, Kazakhstanskii tsentr gosudarstvenno-chastnogo partnerstva, Astana, 2015, pp. 42-46.

3 Biyak L. L. Rol proektnogo menedzhmenta v realizatsii prioritetnykh gosudarstvennykh proektov (The role of project management in the implementation of priority state projects), Aktualnye voprosy ekonomiki i upravleniya: materialy V Mezhdunarodnogo zhurnala nauchnoi konferentsii, Buki-Vedi, 2017, pp. 12-15. - URL: https://moluch.ru/conf/econ/archive/222/12543/ (data obrashcheniya: 04.10.2020).

4 Prikaz Ministra natsionalnoi ekonomiki Respubliki Kazakhstan ot 5 noyabrya 2014 goda No. 69 "Ob utverzhdenii Polozheniya o Ministerstve natsionalnoi ekonomiki Respubliki Kazakhstan". [Elektronnyi resurs]. Rezhim dostupa: http://adilet.zan.kz/rus/docs/V

5 Tkhorikov B. A. Osnovnye elementy proektnogo upravleniya v gosudarstvennom sektore (Key elements of project management in the public sector), Aktualnye voprosy ekonomiki i upravleniya: materialy V Mezhdunarodnogo zhurnala nauchnoi konferentsii, Buki-Vedi, 2017, pp. 138-142. URL: https://moluch.ru/conf/econ/archive/222/12235/ (data obrashcheniya: 04.10.2020).

6 Natsionalnyi standart Respubliki Kazakhstan ST RK ISO 21500-2014 "Rukovodstvo po upravleniyu proektami" (Leadership in project management). [Elektronnyi resurs]. Rezhim dostupa: http://online.zakon.kz/ Document $/$ doc id $=39196466 \#$ pos $=0 ; 0$.

7 Alibekova K. Zh. Aktualnye problemy sovremennogo menedzhmenta v Kazakhstane (Current problems of modern management in Kazakhstan) 2013. [Elektronnyi resurs]. Rezhim dostupa: http://www.rusnauka.com/16 NPRT 2012/Economics/1 111536.doc.htm.

\section{МЕМЛЕКЕТТІК БИЛІК ОРГАНДАРЫНДА ЖОБАЛЫҚ БАСҚАРУДЫ ІСКЕ АСЫРУДЫҢ ҚҰРЫЛЫМДЫҚ ТЕТІКТЕРІ \\ "Г. Султанова, Ж.Сюбебаева, С. Айткулова, А. Кенджасарова \\ «I. Жансүгіров атындавы Жетісу университеті» КЕ АҚ, Талдықорван, Қазақстан e-mail:king_bara@mail.ru}

Түйін. Мақалада жобалық менеджмент пен жобалық менеджменттің теориясы мен ддістемесі қазіргі уақытта барлық дамыгеан елдердегі мемлекеттік басқарудың негізі болып табылатындывы қарастырылады. Бұл салада ұлттық және халықаралық стандарттар бекітілді, тиісті заңнамалық база қалыптастырылды. Қазақстанда жобаларды басқару парадигмасы да мемлекеттік деңгейде қабылданды. Бұван биліктің барлық деңдейіне "енетін" "қолжетімді және жайлы тұрвын үй", "денсаулық сақтау", "сапалы білім беру", "агроөнеркәсіптік кешенді дамыту" сияқты басым ұлттық жобалардың қабылдануы мысал бола алады. Басқама айтқанда, "жобалық менеджмент" деп аталатын менеджмент саласы дамудың инновачиялық моделіне көшу жавдайында қазақстандық валымдардың, коммерчиялық ұйымлдардың да, мемлекеттік биліктің барлық деңгейіндегі атқарушы билік органдарының да мамандары мен басмыларының жіті назарында болады. Мұның себебі жобалық менеджментті тиімді және тиімді басқарудың заманауи философиясы ретінде жаһандық тану болып табылады.

Түйін сөздер: мемлекеттік басқару, жобаларды басқару, әкімшілік реформа, менеджмент, мемлекет.

\section{СТРУКТУРНЫЕ МЕХАНИЗМЫ РЕАЛИЗАЦИИ ПРОЕКТНОГО УПРАВЛЕНИЯ В ОРГАНАХ ГОСУДАРСТВЕННОЙ ВЛАСТИ \\ "Г. Султанова, Ж. Сюбебаева, С. Айткулова, А. Кенджасарова \\ НАО «Жетысуский университет им.И. Жансугурова», Талдыкорган, Казахстан \\ e-mail:king_bara@mail.ru}

Резюме. В статье рассматривается то, что теория и методология проектного менеджмента и проектного менеджмента в настояшее время являются основой государственного управления во всех развитых странах. В этой области утверждены начиональные и международные стандарты, сформирована соответствуюшая законодательная база. В Казахстане парадигма управления проектами также принята на государственном уровне. Примером тому служит принятие приоритетных наииональных проектов "доступное и комфортное жилье", "здравоохранение", "качественное образование", "развитие агропромыииленного комплекса", которые "пронизывают" все уровни власти. Иными словами, сфера менеджмента, именуемая "проектным менеджментом", в условиях перехода к инновационной модели развития становится 
предметом пристального внимания казахстанских ученых, специалистов и руководителей как коммерческих организаций, так и органов исполнительной власти всех уровней государственной власти. Причиной этого является глобальное признание проектного менеджмента как современной философии эффективного и результативного менеджмента.

Ключевые слова: государственное управление, управление проектами, административная реформа, менеджмент, государство.

IRSTI 06.73

UDC 338.001

https://doi.org/10.51579/1563-2415.2021-1.20

\title{
MUNICIPAL INFRASTRUCTURE PROJECT IN THE DEVELOPMENT OF INFRASTRUCTURE IN KAZAKHSTAN
}

\author{
I.Y. Khan* ${ }^{1}$, A.B. Abylkasym ${ }^{2}$, A.J. Kurmantayeva ${ }^{3}$, A.R. Shalbayeva
}

${ }^{1}$ Miras University, Shymkent, Kazakhstan

${ }^{2}$ Shymkent University, Shymkent, Kazakhstan

${ }^{3}$ KazNPU named after Abay, Almaty city, Kazakhstan

${ }^{4}$ International humanitarian and technical University, Shymkent, Kazakhstan

e-mail:musik711@mail.ru

Annotation. The study focuses on the financing of infrastructure projects using municipal bonds.

Originality of the research. The article considers a set of measures designed to activate the process of attracting investment in infrastructure at the municipal level using bonds. The parameters of securities issues of concessionaires were studied, and the experience of managing municipalities with securities as an element of debt policy was analyzed.

Research result. The results of the research can be useful both in developing the financial policy of the state management of spatial development at the national and regional levels, and in conducting further research on the activation of the investment process in Kazakhstan at the municipal level.

Key words: municipal bonds, infrastructure, projects, activation, management.

Basic provisions. The achievement of outstripping growth in the competitiveness of the regional economy as a result of the use of municipal infrastructure projects, which contributes to the emergence of synergistic and multiplicative effects, in comparison with the use of investments, is justified. For the first time, the authors propose an algorithm for methodological justification of the effectiveness of the use of municipal infrastructure projects in order to increase the competitiveness of the regional economy and decisions on the feasibility of using municipal infrastructure projects.

Introduction. One of the key features that has historically been critical for our country is the significant heterogeneity of territorial development.

The combination of geographical, economic, socio-demographic factors creates a certain imbalance in the spatial development of the Republic of Kazakhstan, which has been repeatedly noted by Kazakh scientists as an obstacle to the sustainable growth of the country's economy.

Of course, there is a similar imbalance in other countries [1].

But modern experience, including foreign experience, shows that the already established model of simple redistribution of part of income between unevenly developing regions of the country through the mechanism of the budget process is losing its effectiveness [2,3]. In the process of such redistribution between the donor and recipient regions, the prerequisites for intensive economic growth of the latter are not formed.

The main task in this case should be the mechanism of not just redistribution, but the intensification of economic processes, which is a direct consequence of creating conditions that are attractive for life. A key factor in the decision is the qualitative growth of investment in the region's infrastructure.

Materials and methods. The problem of municipal infrastructure deficit (taking into account the territorial conditions of Kazakhstan, especially its length and spatial disproportionality) is of particular importance.

Until recently, only current or average repairs of road networks and infrastructure facilities were carried out in this area, which did not affect the improvement of the living environment.

In turn, the coordinated and progressive development of municipal infrastructure not only contributes to the retention of the local population, but also increases the investment and migration attractiveness of the territories.

Results and discussion. The acute urgency of the problem of state competitiveness clearly indicates the need to strengthen territorial connectivity. However, the practical result of this strategy does not involve the renovation of municipal infrastructure, although the infrastructure library scheme is most preferable for municipalities $[4,5]$. At the 